\title{
A Research on Profitability and Dividend using Arima Model with Reference to Steel Sector
}

\author{
P.Venkatesh, A.Krishna Sudheer, D.Sathya Prasad Kumar, Senthil Murugan.P
}

\begin{abstract}
In India Indian, Iron and Steel Industry plays significantly for the overall growth and development of the country. Based on the budget of Ministry of Steel declares that steel industry contributes $2 \%$ of the Indias GDP, and its weight is $6.2 \%$ in the Index of Industrial Production(IPP). The sector able to grow by itself globally. In India steel production in one Million Tones in 1947, now its become the world's $2^{\text {nd }}$ largest producer next to China. India's GDP declines 5\% in 2019 on account of rising Inflation, GST and strict monetary control. This medium made the domestic demand weeker which grew 3.3\% in 2019, Despite the rise in last Quater.
\end{abstract}

Key Words: Steel, Production, Inflation, Demand....etc.,

\section{INTRODUCTION OF THE STUDY}

In the present context, the Steel sector is to be considered as the dominating industry in the tremendous growth of the economy. Based on the forecasting of the bureau of steel, Steel sector at the moment contributes to $2 \%$ in India's National Income and its impact in the official directory of Industrial Production (IPP) is $6.2 \%$. The steel sector creates an increasing impact globally. At the time of Independence steel sector produces one million tones, now manufacturing in the highest capacity and developed into the world's $4^{\text {th }}$ most prominent manufacturer of rough steel behind next to China, Japan, and the US. Crude steel manufacturing grew by $5.6 \%$ to 82.2 million tonnes and steel demand enlarged by $1.08 \%$. The country's GDP growth has melt downward to $6 \%$ in 2019 on the account of rise in the price, GDP and Tough monetary policy. From the Figures indicated to pathetic home steel requirement, that increased by $3.03 \%$ in 2016 , in respect of growth in productivity in the last segment of the year.

With the help of infrastructure construction and urbanization rising as serious development indicators, the country realizing the growth in import of steel in upcoming years. These will consequence in India converting into the largest exporter of crude steel in Year 2015-16 after 6 years. The overall quantity of steel exports by country for the Financial Year stands at 6.59 million tonnes, and it did imports of 6.44 million tonnes as per the data published by the Joint Plant Committee (JPC). India's GDP is forecasted to grow by $5.01 \%$, and steel demand is anticipated to rise by $3.03 \%$ in 2019 . Nevertheless, in the last 3 years,

Revised Manuscript Received on 14, October 2019.

Dr. P.Venkatesh, Assistant Professor, Sri Sairam Engineering College, Chennai, Tamilnadu, India.

Dr. A.Krishna Sudheer, Professor \& Head, G.Pullaiah College of Engineering \& Tech., Kurnool, AndhraPradesh, India.

Dr. D.Sathya Prasad Kumar, Assistant Professor, Voorhees College, Vellore, Tamilnadu, India.

Mr. Senthil Murugan.P, Assistant Professor, Christ University, Bangalore, Karnataka, India. enlargement in this sector has been just $5.01 \%$. With the development of economic activities, the National Steel Policy 2012 is proposed to gives speedy development and enlargement of the country steel industry by tremendous fast capacity accumulation. In the present context, our country dedicated to sinking GHG Emission Extractions of its GDP to $20-25 \%$ by 2010 over the 2006 level, from adaptation of positive strategies.

\section{OBJECTIVES OF THE ANALYSIS}

1. To analyze the various impact of profit indicators on equity performance of selected steel sector in India.

2. Estimate the growth rate and forecast the impact of the profit and liquid position of the selected steel sector.

3. Recognize the variance between the performance of profitability and liquidity of steel companies in India.

4. To identify the dividend progress and growth percentile of the steel sector in India.

5. To find out the various financial factors that vary for a dividend payment of steel companies.

\section{REVIEW OF LITERATURE}

Krishnamoorthy (2012), encompass establish that the sector belongs to the steel and iron ore industry maintain a significant level of profit, the profit growth level determines by variation in gross profit, net profit, operating profit, return on investment and dividend payout ratio. The outcome that there are no similarities among net profit and operating profit between the select companies, and there is no difference in return on Investment of chosen companies in India.

Venkatesan and Nagarajan (2012), investigated that profitability merely depends upon the improved utilization of resources, discontinue expenses and quality of management purpose in the products, customer services and in the workforce, goodwill and market share. It is meaningful to enlarge the production capacity, and use of higher technology to reduce the cost of production and wage progress profitability, not only the investment but also investors' return. These are helping to get better the financing, but also investors return point of view. These are helping to understand better the profitability of selected steel companies in India in prediction.

Krishnamoorthi M. (2016), studied how the dividend payment determined by core steel companies in India, he confidential steel companies as Large-cap and Midcap base on market capitalization, he analyzes concerning the effect 


\section{A RESEARCH ON PROFITABILITY AND DIVIDEND USING ARIMA MODEL WITH REFERENCE TO STEEL SECTOR}

of liquidity, turnover, and profitability on dividend payment of steel sector and he finished that a lot of factors that influence the factor of dividend namely Return on Assets, Return on net worth, Debtors Turnover Ratio, and Gross Profit Margin and Net profit margin among the large-cap and midcap companies.

Krishnamoorthy M. and Venkatesh.P (2017), assess financial liquidity and profitability location of Select Pharmaceutical Companies in India, and describe the Financial cash is mutual with profitability are the core participant of venture activities which, to function efficiently and effectively, the company should give customary significant. At last, they conclude that the different monetary variables such as liquidity and profitability which persuade in companies' performance throughout the study and there were a few ups and downs in the profitability, but it is not artificial the operations of the company to an immense coverage.

\section{METHODOLOGY OF RESEARCH}

\section{Research Design}

The present analysis is analytical in nature. In this study, stratified random sampling is used. The researcher has taken 10 years to study the financial performance of the steel sector from 2006-2007 to 2015-2016.

\section{Sampling Design For Selection Of Companies}

To examine the profit, dividend performance, and Earning per share of steel companies, the information of 72 companies are evaluated. From the basis of the analysis the steel companies which fulfilled the below criteria which have selected for further study:

$>\quad$ The selected companies are listed and registered in both NSE and BSE.

$>$ The above companies have availability of data for at least 10 years.

$>$ The selected company must attain profit continuously for 3 years through the period of study.

$>\quad$ The companies must be paid a dividend for the last 3 years throughout the study period.

The below steel companies have divided as largecap and mid \& small-cap companies on the basis of market capitalization.

The selected companies stocks must have with a market capitalization of Rs.10, 000 crores or more are Large-Cap Companies and which are listed below:

Large-cap companies: Tata Steel LimitedSteel Authority of India Limited (SAIL), JSW Steel Limited.

The selected companies stock with a market capitalization between Rs.1crores to Rs.10 crore is Mid \& Small-Cap companies and which are selected below.

Mid Cap \& Small Cap Companies: Jindal Steel and Power Limited (JSPL), Bhushan Steel Limited, Kalyani Steel Limited, Hisar Metal Industries Limited.

$\begin{array}{ll}\text { Number of residuals } & 10 \\ \text { Standard error } & 62.437153 \\ \text { Log-likelihood } & -54.403183 \\ \text { AIC } & 116.80637 \\ \text { SBC } & 118.01671\end{array}$

Table 4.42. Variables in the ARIMA Model for Tata Steel

\begin{tabular}{|l|l|l|l|l|}
\hline & B & SEB & $\begin{array}{l}\text { T- } \\
\text { RATIO }\end{array}$ & $\begin{array}{l}\text { APPRO } \\
\text { X. } \\
\text { PROB }\end{array}$ \\
\hline AR1 & -.20011 & .45025 & $\begin{array}{l}-.444445 \\
6\end{array}$ & $\begin{array}{l}.672302 \\
52\end{array}$ \\
\hline MA1 & .97719 & 7.74245 & $\begin{array}{l}.126211 \\
4\end{array}$ & $\begin{array}{l}.903687 \\
71\end{array}$ \\
\hline YEAR & -31.34599 & 3.79745 & $\begin{array}{l}- \\
8.25449 \\
45\end{array}$ & $\begin{array}{l}.000170 \\
94\end{array}$ \\
\hline $\begin{array}{l}\text { CONSTA } \\
\text { NT }\end{array}$ & 63529.820 & 7638.563 & $\begin{array}{l}8.31698 \\
58\end{array}$ & $\begin{array}{l}.000163 \\
90\end{array}$ \\
\hline
\end{tabular}

Inference

The above table 4.42 shows the average share price of Tata Steel for the past ten years. The ARIMA model was used to find out significant forecasting of Average share price of Tata steel, the $\mathrm{p}$-value of the constant, first and second lag is very less. This shows that the fit is good, and the log-likelihood is negative.

The model equation is fitted as,

Average share, Price $(t)=63529.82043+-.20011 * X$ $(t-1)+62.437153$

\section{Arima Modeling For Sail}

Final parameters:

Number of residuals $\quad 10$

Standard error $\quad 52.763382$

Log-likelihood $\quad-51.862965$

AIC $\quad 111.72593$

SBC 112.93627

Table 4.43. Variables in the ARIMA Model for SAIL

\begin{tabular}{|l|l|l|l|l|}
\hline & B & SEB & $\begin{array}{l}\text { T- } \\
\text { RATIO }\end{array}$ & $\begin{array}{l}\text { APPRO } \\
\text { XROB }\end{array}$ \\
\hline AR1 & -.62874 & 1.388 & $\begin{array}{l}-453026 \\
4\end{array}$ & $\begin{array}{l}.6664508 \\
8\end{array}$ \\
\hline MA1 & -.47154 & 1.571 & $\begin{array}{l}-300217 \\
1\end{array}$ & $\begin{array}{l}.7741414 \\
5\end{array}$ \\
\hline YEAR & -11.06840 & 5.354 & $\begin{array}{l}-2.06714 \\
51\end{array}$ & 0 \\
\hline CONSTA & 22381.885 & 10770.4 & $\begin{array}{l}2.07808 \\
08\end{array}$ & .0829547 \\
NT & 18 & 60 & & \\
\hline
\end{tabular}

\section{DATA ANALYSIS AND INTERPRETATIONS \& RESULTS}

Arima Modeling For Tata Steel

Final parameters:
Published By: 


\section{Inference}

The above table 4.43 shows the average share price of SAIL for the past ten years. The ARIMA model was used to find out significant forecasting of the Average share price of SAIL, the p-value of the constant, first and second lag is very less. This indicates that the fit is excellent, and the loglikelihood is negative.

The model equation is fitted as,

Average share, Price $(t)=22381.88518+-.62874 * X$ $(\mathrm{t}-\mathbf{1})+\mathbf{5 2 . 7 6 3 3 8 2}$

\section{Arima modeling for jsw steel}

\section{Final parameters:}

$\begin{array}{ll}\text { Number of residuals } & 10 \\ \text { Standard error } & 183.05672 \\ \text { Log-likelihood } & -64.732788 \\ \text { AIC } & 137.46558 \\ \text { SBC } & 138.67592\end{array}$

Table 4.44. Variables in the ARIMA Model for JSW Steel

\begin{tabular}{|l|l|l|l|l|}
\hline & B & SEB & $\begin{array}{l}\text { T- } \\
\text { RATIO }\end{array}$ & $\begin{array}{l}\text { APPRO } \\
\text { X. } \\
\text { PROB }\end{array}$ \\
\hline AR1 & .34681 & .88595 & $\begin{array}{l}.391451 \\
6\end{array}$ & $\begin{array}{l}.708987 \\
45\end{array}$ \\
\hline MA1 & .95854 & 5.38453 & $\begin{array}{l}.178016 \\
8\end{array}$ & $\begin{array}{l}.864567 \\
96\end{array}$ \\
\hline YEAR & 44.32480 & 15.01491 & $\begin{array}{l}2.95205 \\
18\end{array}$ & $\begin{array}{l}.025544 \\
87\end{array}$ \\
\hline $\begin{array}{l}\text { CONSTA } \\
\text { NT }\end{array}$ & $\begin{array}{l}88350.574 \\
49\end{array}$ & $\begin{array}{l}30202.508 \\
03\end{array}$ & $\begin{array}{l}- \\
2.92527 \\
28\end{array}$ & $\begin{array}{l}.026449 \\
20\end{array}$ \\
\hline
\end{tabular}

\section{Inference}

The above table 4.44 shows the average share price of JSW Steel for the past ten years. The ARIMA model was used to find out significant forecasting of Average share price of JSW Steel, the p-value of the constant, first and second lag is very less. This indicates that the fit is excellent, and the log-likelihood is negative.

The model equation is fitted as,

Average share, Price $(t)=-\mathbf{8 8 3 5 0 . 5 7 4 4 9}+.34681 * X$ $(t-1)+183.05672$

\section{Arima modeling for jindal steel and power ltd}

Final parameters:

Number of residuals

10

Standard error

1192.2512

Log-likelihood

$-83.582405$

AIC

175.16481

SBC

176.37515

Table 4.45. Variables in the ARIMA Model for Jindal Steel and Power Ltd.

\begin{tabular}{|l|l|l|l|l|}
\hline & B & SEB & $\begin{array}{l}\text { T- } \\
\text { RATIO }\end{array}$ & $\begin{array}{l}\text { APPRO } \\
\text { X. } \\
\text { PROB }\end{array}$ \\
\hline AR1 & .29316 & .60025 & $\begin{array}{l}.488394 \\
5\end{array}$ & $\begin{array}{l}.642605 \\
75\end{array}$ \\
\hline MA1 & .98315 & 8.21820 & $\begin{array}{l}.119630 \\
9\end{array}$ & $\begin{array}{l}.908680 \\
67\end{array}$ \\
\hline YEAR & - & 95.60913 & - & .004574 \\
\hline
\end{tabular}

\begin{tabular}{|l|l|l|l|l|}
\hline & 420.55786 & & $\begin{array}{l}4.39872 \\
05\end{array}$ & 69 \\
\hline CONSTA & 847159.45 & 192317.82 & 4.40499 & .004543 \\
NT & 777 & 721 & 70 & 81 \\
\hline
\end{tabular}

Inference

The above table 4.45 shows the average share price of Jindal steel and power ltd. For the past ten years. The ARIMA model was used to find out significant forecasting of the Average share price of Jindal steel and power ltd, the p-value of the constant, first and second lag is very less. This indicates that the fit is excellent, and the log-likelihood is negative.

The model equation is fitted as,

Average share, Price $(t)=847159.45777+.29316 * X$ $(t-1)+1192.2512$

Arima modeling for bhushan steel

Final parameters:

Number of residuals $\quad 10$

Standard error $\quad 356.68263$

Log-likelihood $\quad-71.076485$

AIC $\quad 150.15297$

SBC 151.36331

Table 4.46. Variables in the ARIMA Model for Bhushan Steel

\begin{tabular}{|l|l|l|l|l|}
\hline & B & SEB & $\begin{array}{l}\text { T- } \\
\text { RATIO }\end{array}$ & $\begin{array}{l}\text { APPRO } \\
\text { X. } \\
\text { PROB }\end{array}$ \\
\hline AR1 & -.90473 & 1.525 & $\begin{array}{l}-.593306 \\
7\end{array}$ & $\begin{array}{l}.574643 \\
72\end{array}$ \\
\hline MA1 & -.99820 & 30.499 & $\begin{array}{l}-.032729 \\
3\end{array}$ & $\begin{array}{l}.974952 \\
07\end{array}$ \\
\hline YEAR & -61.83953 & 40.887 & $\begin{array}{l}- \\
1.51246\end{array}$ & $\begin{array}{l}.181174 \\
96\end{array}$ \\
\hline $\begin{array}{l}\text { CONSTA } \\
\text { NT }\end{array}$ & 124941.961 & $\begin{array}{l}82243.3 \\
69\end{array}$ & $\begin{array}{l}1.51917 \\
37\end{array}$ & $\begin{array}{l}.179524 \\
39\end{array}$ \\
\hline
\end{tabular}

Inference

The above table 4.46 shows the average share price of Bhushan Steel for the past ten years. The ARIMA model was used to find out significant forecasting of Average share price of Bhushan Steel, the p-value of the constant, first and second lag is very less. This indicates that the fit is excellent, and the log-likelihood is negative.

The model equation is fitted as,

Average share, Price $(t)=124941.96191+-.90473 * X$ $(t-1)+356.68263$ 
Arima modeling for kalyani steel

Final parameters:

Number of residuals 10

Standard error $\quad 98.234435$

Log-likelihood $\quad-58.197023$

AIC $\quad 124.39405$

SBC 125.60439

Table 4.47. Variables in the ARIMA Model for KALYANI STEEL

\begin{tabular}{|c|c|c|c|c|}
\hline & B & SEB & $\begin{array}{l}\text { T- } \\
\text { RATIO }\end{array}$ & $\begin{array}{l}\text { APPRO } \\
\text { X. PROB }\end{array}$ \\
\hline AR1 & -.30292 & .69250 & $\begin{array}{l}. \\
.4374257\end{array}$ & $\begin{array}{l}.6771084 \\
9\end{array}$ \\
\hline MA1 & -.76140 & .60518 & $\begin{array}{l}- \\
1.258148 \\
6\end{array}$ & $\begin{array}{l}.2550822 \\
0\end{array}$ \\
\hline YEAR & -25.27985 & 13.75892 & $\begin{array}{l}- \\
1.837342 \\
4\end{array}$ & $\begin{array}{l}.1158038 \\
8\end{array}$ \\
\hline $\begin{array}{l}\text { CONSTAN } \\
\mathrm{T}\end{array}$ & $\begin{array}{l}51006.1483 \\
6\end{array}$ & $\begin{array}{l}27676.1040 \\
4\end{array}$ & $\begin{array}{l}1.842967 \\
1\end{array}$ & $\begin{array}{l}.1149047 \\
0\end{array}$ \\
\hline
\end{tabular}

Inference

The above table 4.47 shows the average share price of Kalyani Steel for the past ten years. The ARIMA model was used to find out significant forecasting of Average share price of Kalyani Steel, the p-value of the constant, first and second lag is very less. This indicates that the fit is excellent, and the log-likelihood is negative.

The model equation is fitted as,

Average share, Price $(t)=51006.14836+-.30292 * X$ $(\mathrm{t}-1)+98.234435$

\section{Arima modeling for hisar metal}

Final parameters:

Number of residuals $\quad 10$

Standard error $\quad 3.9716506$

Log-likelihood $\quad-26.227524$

AIC $\quad 60.455048$

SBC 61.665388

Table 4.48. Variables in the ARIMA Model for HISAR METAL

\begin{tabular}{|l|l|l|l|l|}
\hline & B & SEB & $\begin{array}{l}\text { T- } \\
\text { RATIO }\end{array}$ & $\begin{array}{l}\text { APPRO } \\
\text { X. } \\
\text { PROB }\end{array}$ \\
\hline AR1 & -.75335 & .77270 & $\begin{array}{l}-974959 \\
4\end{array}$ & $\begin{array}{l}.3672331 \\
5\end{array}$ \\
\hline MA1 & -.99080 & 7.05453 & $\begin{array}{l}-140449 \\
0\end{array}$ & $\begin{array}{l}.8929016 \\
7\end{array}$ \\
\hline YEAR & -.53346 & .48611 & $\begin{array}{l}- \\
1.09740 \\
09\end{array}$ & $\begin{array}{l}.3145435 \\
3\end{array}$ \\
\hline $\begin{array}{l}\text { CONSTA } \\
\text { NT }\end{array}$ & 1098.539 & $\begin{array}{l}977.817 \\
89\end{array}$ & $\begin{array}{l}1.12346 \\
04\end{array}$ & $\begin{array}{l}.3041730 \\
2\end{array}$ \\
\hline
\end{tabular}

Inference
The above table 4.48 shows the average share price of Hisar Metal for the past ten years. The ARIMA model was used to find out significant forecasting of Average share price of Hisar Metal, the p-value of the constant, first and second lag is very less. This indicates that the fit is good, and the log-likelihood is negative.

The model equation is fitted as,

Average share, Price $(t)=1098.53963+-.75335 * X(t-$ 1) $+\mathbf{3 . 9 7 1 6 5 0 6 5 . 3}$

\section{CONCLUSION}

During the current situation, companies have to meet up the international rivalry and generate profit. It is the most important function of organization to assess the company`s financial strength with suitable approach assists in a variety of financial key decision makings, like as Investment assessment and finance decision, Dividend assessment, and profit decision. The assessment creates a essential function in comparing the financial adoptability of steel companies in India. In India steel industries play an essential role in the development of the country`s economic system. The usage of steel products is incresing in the industries of automobiles, infrastructure, white goods, machinery, and tools. This sector is the relied of the organization to save excellent financial position by proper operation and handling of assets or funds, which tends to incresing the profit of the organisation. The current study concludes that the profit of choosen steel sectors reasonable, leaving few belongs to mid-cap \& small-cap companies, these companies make the attempt to improve their financial position to compete domestic and international competition. The companies that belong to same sector to be different in various aspects.

\section{REFERENCE:}

1. Venkatesh.P (2017) An Evaluation of Liquidity and Profitability of Selected Pharmaceutical Companies in India, Journal of Advanced Research in Dynamical \& Control Systems ISSN: 1943-023X, 07-Special issue on Management Studies.

2. Venkatesh.P (2017) "A Descriptive Analysis of Short Term Solvency and Profitability of Selected Pharmaceutical Companies in India" Journal of Advance Research in Dynamical \& Control Systems, ISSN: 1943023X, 07-Special issue on Management Studies.

3. Venkatesh.P (2018) "A Study on Impact of Profit, Earning Per Share And Dividend On Equity Performance On Select Steel Sector Using Discriminant Function Analysis" International Journal of Mechanical and Production Engineering Research and Development (IJMPERD),, ISSN (P): 2249-6890; ISSN (E): 22498001 Vol. 8, Special Issue 3, PP: 998-1007

4. Venkatesh.P (2018) "A Study On Customer Perception Towards Mugi Ultra Liquid Detergent" International Journal of Mechanical and Production Engineering Research and Development (IJMPERD), ISSN (P): 22496890; ISSN (E): 2249-8001 Vol. 8, Special Issue 3, PP: 978-984. 
5. Venkatesh.P (2018) "Saving Habit And Investment Preference Of Government School Teachers In Vellore District" International Journal of Mechanical and Production Engineering Research and Development (IJMPERD), ISSN (P): 2249-6890; ISSN (E): 2249-8001 Vol. 8, Special Issue 3, PP: 922-926. 